\title{
THE THANKSGIVING MEETING IN MISSOURI
}

The two hundred eighty-fourth regular meeting of the Society was held at the University of Missouri on Friday and Saturday, November 28-29, 1930. About sixty persons attended the meeting, among whom were the following thirty-nine members of the society:

V. W. Adkisson, R. P. Agnew, Wealthy Babcock, Herman Betz, F. L. Black, W. C. Brenke, H. C. Carter, J. T. Colpitts, Byron Cosby, H. P. Doole, M. G. Gaba, A. M. Harding, E. S. Haynes, D. L. Holl, H. M. Hosford, Byron Ingold, Louis Ingold, M. H. Ingraham, R. E. Langer, J. V. McKelvey, Wilhelm Maier, C. N. Moore, T. A. Mossman, W. O. Pennell, O. J. Peterson, P. R. Rider, G. E. Robinson, W. H. Roever, L. L. Runge, G. W. Smith, R. G. Smith, Julia Spaulding, E. B. Stouffer, J. S. Turner, G. E. Wahlin, W. D. A. Westfall, J. J. Wheeler, L. P. Woods, E. K. Wyant.

On Friday evening a dinner was held at the Tiger Hotel. This dinner was attended by fifty-seven persons.

On Saturday morning Professor C. N. Moore gave an address on Types of series and types of summability. This was followed by an address by Professor R. E. Langer on Zeros of exponential sums and of certain related functions.

During a recess in the Friday afternoon meeting the local chapter of $\mathrm{Pi} \mathrm{Mu}$ Epsilon served refreshments to those in attendance at the meeting.

Professor E. B. Stouffer and Professor W. D. A. Westfall presided at the session on Friday afternoon, and Professor Louis Ingold at the meeting on Saturday morning. The papers whose abstract numbers are followed by the letter $t$ were read by title. The paper of Professor O. H. Rechard was read by Professor R. E. Langer. Dr. Bourgin was introduced by Professor R. D. Carmichael, and Miss Zeigel by Professor Louis Ingold.

1. A canonical form for the differential equations of curves in n-dimensional space, by Professor R. G. Smith. (Abstract No. 36-9-381.)

2. On ranges of inconsistency of regular transformations, and allied topics, by Dr. R. P. Agnew (National Research Fellow). (Abstract No. 36-11-416.) 
3. On small samples from certain non-normal universes, by Professor P. R. Rider. (Abstract No. 36-11-427.)

4. Periodic motions and surface transformations, by Professor Herman Betz. (Abstract No. 37-1-22.)

5. The cross ratio of the points in which a transversal cuts the sides of a quadrilateral, by Professor J. S. Turner. (Abstract No. 37-1-24.)

6. The expansion problem associated with a class of irregular ordinary differential boundary value problems, by Professor $\mathrm{O}$. $\mathrm{H}$. Rechard. (Abstract No. 36-11-411.)

7. The rank equation of an algebra, by Professor G. E. Wahlin. (Abstract No. 36-11-420.)

8. Principal directions for two-dimensional surfaces in hyperspace, by Miss Marguerite Zeigel. (Abstract No. 36-11-426.)

9. An expansion problem for a first order differential equation where the coefficient of $y$ is $\lambda x^{h},(h>0),(-a<x<b)$, by Dr. H. P. Doole. (Abstract No. 36-11-413.)

10. The determination of the limiting value of the integral used in generalization of a certain lemma, by Dr. H. P. Doole. (Abstract No. 36-11-414-t.)

11. Condition that a locally connected continuum contain an Aleph-Null Bein, by Dr. Leo Zippin (National Research Fellow). (Abstract No. 36-11-415-t.)

12. Note on locally cyclicly connected continua, by Dr. Leo Zippin (National Research Fellow). (Abstract No. 36-11-419-t).

13. A continuous curve in 3-space, by Professor J. H. Roberts. (Abstract No. 36-11-430-t.)

14. Characterization of the sine and cosine by their orthogonality properties, by Dr. D. G. Bourgin. (Abstract No. 37-1-23-t.)

15. Orthogonal properties of elliptic functions. Preliminary report by Dr. Wilhelm Maier. (Abstract No. 37-1-25.)

M. H. IngRaham, Associate Secretary 